Potravinarstvo Slovak Journal of Food Sciences

vol. 15, 2021, p. 254-261

https://doi.org/10.5219/1480

Received: 7 October 2020. Accepted: 17 March 2021.

Available online: 28 March 2021 at www.potravinarstvo.com

(C) 2021 Potravinarstvo Slovak Journal of Food Sciences, License: CC BY X.X

ISSN XXXX-XXXX (online)

\title{
AMINO ACIDS IN ENTERAL FORMULA BASED ON LOCAL FERMENTED FOOD FOR CHILDREN WITH PROTEIN ENERGY MALNUTRITION
}

\author{
Yessie Finandita Pratiwi, Mohammad Sulchan, Diana Nur Afifah, Rusdin Rauf
}

\begin{abstract}
Protein-energy malnutrition still becomes a problem in the world and Indonesia. The enteral formula is needed in the process of fulfilling overall nutrition in the form of a liquid diet in malnourished patients to digest and absorb nutrients without any difficulties. Amino acid lysine, methionine, cysteine, threonine, and tryptophan are often deficits in children's food; even, malnourished children (stunting, wasting, or protein-energy malnutrition) have decreased amino acids. Tempeh gembus, fermented local food, is used as the main ingredient for the enteral formula, and the hydrolysate process is carried out and made into flour, resulting in more amino acids due to the process of protein breakdown. The making of enteral formula from local food fermentation aims to enable the community to optimize local food into more nutritious food so that it can be produced at the household scale. Other supplementary ingredients are isolated soy protein, pumpkin flour, maltodextrin, sugar, and soybean oil. The enteral formula is isocaloric and isoprotein; it is divided into two with different compositions of the hydrolysate of Tempeh gembus flour. This study aims to determine the content of protein, amino acids, and limiting amino acids in the enteral formula. The amino acid analysis was performed using the HPLC method. Amino acid glutamate has the highest content in enteral formulas A and B $\left(2,080 \mathrm{mg} \cdot 100 \mathrm{~g}^{-1}\right.$ and $\left.1,950 \mathrm{mg} \cdot 100 \mathrm{~g}^{-1}\right)$. The total amino acid content of enteral formula $A$ is higher than that of enteral formula B with a difference of $210 \mathrm{mg}^{100 \mathrm{~g}^{-1}}$. Enteral formula A has a higher average amino acid content $\left(1,400 \mathrm{mg} \cdot 100 \mathrm{~g}^{-1}\right)$ than enteral formula B $\left(1,378 \mathrm{mg} \cdot 100 \mathrm{~g}^{-1}\right)$, and there is no significant difference $(p=$ 0.812) between them. The enteral formula $A$ has a higher amino acid content, but the highest protein content is in enteral formula B. The limiting amino acids in enteral formulas A and B are the methionine amino acids. Enteral formulas A and B can fulfill the needs of amino acids and be an alternative formula for Children with PEM.
\end{abstract}

Keywords: Tempeh gembus flour hydrolysate; amino acid; enteral formula; toddler; PEM

\section{INTRODUCTION}

Protein-energy malnutrition (PEM) indicates a health problem caused by an imbalanced consumption of macronutrients such as protein, thus causing the occurrence of kwashiorkor as a form of protein-energy malnutrition and even death (Ngo and Serra-Majem, 2018; Anggraeny et al., 2016). The prevalence of protein-energy malnutrition in the world as of March 2020 is $5-7 \%$ or around $40,000-47,000$ children, a decrease from year to year, and in Asia in 2016 and 2017 decreased while in 2018 it had not changed. However, in 2019, it had increased to be categorized as the highest prevalence of more than 15\% (UNICEF, WHO, World Bank Group, 2019; UNICEF, WHO, World Bank Group, 2020).

Risk factors for malnutrition include Low Birth Weight (LBW), non-exclusive breastfeeding, inappropriate complementary feeding, and recurrent infectious diseases (Bhutta and Salam, 2012). The problem of food insecurity, low access to quality and quantity of food, and low sanitation also affect the growth and development of children (Ngo and Serra-Majem, 2018; Cooper, 2010). Malnutrition has synergism in infectious diseases and influences morbidity and mortality (Ashworth, 2017).

One of the treatments for children with PEM is the administration of enteral formulas to fulfill their nutritional needs (Pratiwi and Noer, 2014) in the form of liquid diet foods (Ariani et al., 2013). The enteral formula has a liquid to viscous texture because children with PEM experience disorders including chewing and swallowing disorders and keep the gastrointestinal work physiologically (Damayanti et al., 2012). The administration of enteral formula has been shown to increase body weight quickly in children with PEM (Chusnatayaini et al., 2018) and maintain normal nutritional status (Sousa et al., 2014). Modified Dried Skimmed Milk Coconut Oil (modisco) enteral formula is commonly used for suboptimal therapy in compensating for protein deficiency. This is due to the occurrence of protein 
malabsorption due to protease enzyme deficiency (Kamalia and Sulistyaningsih, 2014).

The enteral formulas made from Tempeh gembus with other components are isolated soy protein, pumpkin flour, maltodextrin, granulated sugar, and soybean oil. Tempeh gembus is a common fermented product in Indonesia and is made from tofu dregs with the Rhizopus oligosporus microorganism (Sulchan and EndangNur, 2007). Food fermentation has a benefit as a preservation technique to improve sensory properties and nutritional value (Bujang and Taib, 2014). Tempeh gembus has proteolytic activity (Afifah et al., 2014) if bromelain enzyme is added can break peptide bonds to proteins into amino acids quickly (Widjaja et al., 2013; Wijaya and Yunianta, 2015; Kurniasari et al., 2017), and the function of bromelain enzyme to biocatalysts in protein breakdown (Kumaunang and Kamu, 2010). Tempeh gembus is processed into flour to increase the shelf life so that it inhibits the growth of microorganisms and chemical reactions (Karyadi et al., 2012; Astawan et al., 2015). The soy protein isolated flour is added to increase nutritional value because it has high protein content (Rauf and Utami, 2020) and children with PEM needs more protein; on the other hand, isolated soy protein is one component of protein in enteral formula (Brown et al., 2014). Pumpkin flour has high energy and protein content (Nakon et al., 2017; USDA., 2018). The function of adding maltodextrin to stabilize the enteral formula because the characteristic is soluble so influences the value of viscosity (Rauf and Utami, 2020). The addition of sugar can increase carbohydrate intake while the addition of soybean oil in the enteral formula can fulfill the intake of protein and fat (Dietitians Association of Australia, 2018).

Protein contains structural and functional components in living systems derived from food consumption. Protein is found in skeletal muscle by $40 \%$, in body organs by more than $25 \%$, and in the skin and blood (Gropper and Smith, 2013). Food proteins contain essential amino acids for the body (Boye et al., 2012). Amino acids have a very important component to see the quality of protein and physiology in the body. Amino acids are related to the body because they are needed in a variety of reactions and biochemical mechanisms, so the function of an organism runs normally and maintains its health status. Essential amino acids can only be found in food. Tempeh gembus (netto) has the highest amino acid composition (glutamate of $0.29 \%$ ) while the lowest amino acid is methionine $(0.01 \%)$. The highest amino acid content in dried Tempeh gembus is threonine $(0.95 \%)$ and the lowest is serine $(0.07 \%)$. Amino acid levels in Tempeh gembus are smaller than in soybean Tempeh (Sulchan and EndangNur, 2007).

The first limiting amino acid is an amino acid with the smallest score used as a limitation on the biological value of a food protein. Lysine, tryptophan, and sulfuric amino acids are limiting amino acids in food products based on soybean (Ribarova, 2018). Methionine and cysteine or sulfuric amino acids are limiting essential amino acids in soybeans (Serna-saldivar et al., 2019). This study is aimed at investigating whether enteral formulas A and B have high protein and amino acid content that can fulfill the needs and be an alternative formula for Children with PEM.
Scientific hypothesis

Enteral formulas A and B based on local fermented food can fulfill the amino acids needed by children with PEM.

\section{MATERIAL AND METHODOLOGY \\ Samples}

The samples of this study are enteral formulas A and B, which have the composition of a hydrolysate of Tempeh gembus flour, isolated soy protein, pumpkin flour, maltodextrin, sugar, and soybean oil.

\section{Chemicals}

Bromelain enzyme brand Pinecaps (powder) used to hydrolysate of Tempeh gembus. Bromelain enzyme from Rumah Sehat Yogyakarta City, Indonesia. Isolated soy protein brand Marksoy was obtained from an online shop in Subang Regency, West Java, Indonesia. Maltodextrin food grade $(10-12 \mathrm{DE})$ brand Lansida was obtained from an online shop in Yogyakarta City, Indonesia.

\section{Instruments}

The formula was based on the recommendation of ASPEN (American Society for Parenteral and Enteral Nutrition). Enteral formulas A and B are isocaloric, $200 \mathrm{kcal} / 200 \mathrm{~mL}$ consists of $20 \mathrm{kcal}$ protein, $60 \mathrm{kcal}$ fat, and $120 \mathrm{kcal}$ carbohydrate. Furthermore, the need for each ingredient was determined using Algebra equation, as follow (Knapp, 2016):

\section{$(\mathrm{AxWxCp})+(\mathrm{BxWxCp})+(\mathrm{CxWxCp})=20 \mathrm{kcal}$ protein}

Where :

$\mathrm{A}=$ Hydrolysate of Tempeh gembus (\%); B = Isolated soy protein $(\%) ; \mathrm{C}=$ Pumpkin flour $(\%) ; \mathrm{W}=$ Weight of enteral formula; $\mathrm{Cp}=$ calorie of protein $\left(\mathrm{kcal} . \mathrm{g}^{-1}\right)$.

$$
(\mathrm{AxWxCp})+(\mathrm{CxWxCp})+(\mathrm{ExWxCp})=60 \mathrm{kcal} \text { fat }
$$

Where :

$\mathrm{A}=$ Hydrolysate of Tempeh gembus (\%); C = Pumpkin flour $(\%) ; \mathrm{E}=$ Soybean oil (\%); $\mathrm{W}=$ Weight of enteral formula $\mathrm{Cp}=$ calorie of fat $\left(\mathrm{kcal} \cdot \mathrm{g}^{-1}\right)$.

\section{$(\mathrm{AxWxCp})+(\mathrm{CxWxCp})+(\mathrm{DxWxCp})+(\mathrm{FxWxCp})=120 \mathrm{kcal}$ carbohydrate}

Where :

$\mathrm{A}=$ Hydrolysate of Tempeh gembus $(\%) ; \mathrm{C}=$ Pumpkin flour $(\%) ; \mathrm{D}=$ Maltodextrin (\%); F = Sugar (\%); W = Weight of enteral formula; $\mathrm{Cp}=$ calorie of carbohydrate $\left(\mathrm{kcal} . \mathrm{g}^{-1}\right)$.

In this study, it was estimated that $50 \mathrm{~g}$ of the enteral formula $\mathrm{A}$ and $60 \mathrm{~g}$ of the enteral formula B. Food ingredients contain the protein are included in the protein equation, as well as fats and carbohydrates.

Based on Table 1, the weight of each ingredient from the calculation of algebraic equation from protein, fat, and carbohydrate. Enteral formula A has the lowest composition of the Tempeh gembus flour, but the highest composition of other components compared to enteral formula B. On the other hand, enteral formula B has the highest composition of Tempeh gembus flour, but the lowest composition of other components compared to enteral formula A. 


\begin{tabular}{lcc} 
Table 1 Calculation of enteral formulas A and B. \\
\hline Materials & $\begin{array}{c}\text { Enteral } \\
\text { Formula A (g) }\end{array}$ & $\begin{array}{c}\text { Enteral } \\
\text { Formula B } \\
\text { (g) }\end{array}$ \\
\hline $\begin{array}{lcc}\text { Hydrolysate } \\
\text { Tempeh gembus }\end{array}$ & 25 & 36 \\
Flour & & \\
Isolated Soy Protein & 2.211 & 1.962 \\
Pumpkin Flour & 5.942 & 5.809 \\
Maltodextrin & 5 & 5 \\
Soybean Oil & 3.305 & 3.292 \\
Sugar & 8.813 & 8.29 \\
Total & 50.269 & 60.353 \\
\hline
\end{tabular}

Other components in enteral formulas A and B have a very small difference compared to the composition of the hydrolysate Tempeh gembus flour.

The calculation is based on the protein requirements of malnourished toddlers who have entered the rehabilitation phase. The nutritional needs of malnourished children in the rehabilitation phase are $150-220 \mathrm{kcal} / \mathrm{kgBW} /$ day, protein $4-6 \mathrm{~g} / \mathrm{kgBW} / \mathrm{day}$, and liquid 150 $200 \mathrm{~mL} / \mathrm{kgBW} /$ day (WHO, 2009).

\section{Laboratory Methods}

High-Performance Liquid Chromatography (HPLC) technique (IK.LP-04.7-LT-1.0) is used as the amino acid testing standard in the Integrated Laboratory of the Bogor Institute of Agriculture. HPLC consists of 4 steps, that are making protein hydrolysate, drying, derivatization, injection and amino acid analysis. Calculation of Amino Acid Score (AAS) in $\mathrm{mg}$ of limiting amino acid in $1 \mathrm{~g}$ test protein (product) divided with $\mathrm{mg}$ amino acid in the required pattern for a child (1-2 years)(FAO Food and Nutrition, 2013). Amino acid scores were truncated to 1.00 if the score greater than 1.00 (Hughes et al., 2011).

\section{Description of the Experiment}

Samples preparation: The main component of the enteral formula is Tempeh gembus made from local soybean pulp fermented by Rhizopus sp. Tempeh gembus is obtained from a Tempeh maker in the Semarang Indah area, Semarang City, Indonesia. The deposition of Tempeh gembus was conducted in the laboratory of the Faculty of Agricultural Technology of GadjahMada University, Yogyakarta City, Indonesia. Pumpkin flour was obtained from the Center for Food and Nutrition Studies Laboratory of GadjahMada University, Yogyakarta City, Indonesia. Sugar brand Gulaku and soybean oil brand Mazola were obtained from a supermarket in Semarang City, Indonesia. The process of making hydrolysate of Tempeh gembus is bromelain enzyme brand Pinecaps 500 ppm (1 capsule) added in 100 gram Tempeh gembus and wait for 30 minutes. Enteral formula A (50 grams) served for one-time consumption and 60 grams of enteral formula B served for one-time consumption. The enteral formula is served by mixing all the ingredients then added $200 \mathrm{~mL}$ of hot water at $90{ }^{\circ} \mathrm{C}$, and stirred until dissolved.

Number of samples analyzed: Enteral formulas A and B.

Number of repeated analyses: Enteral formulas A and B in duplicate.
Statistical analysis

The data were analyzed using SPSS version 20.0 Amino acid testing in duplicate. Shapiro-Wilk test was used to know the distributed data. The Mann Whitney test was used for statistical analysis because the data were not normally distributed $(p<0.05)$.

\section{RESULTS AND DISCUSSION}

Enteral formula based on Tempeh gembus flour is a modified form of enteral formula with high protein content. This formula is given to children with PEM entering the rehabilitation phase, a recovery phase that aims to increase children's growth. Therefore, enteral formula based on local food with high nutritional value can be an alternative food given to children with PEM (Sholihah and Noer, 2014).

The resulting enteral formula is high in energy and protein values. Enteral formula A has a protein content (\%) of $15.215 \pm 0.021$ and enteral formula $\mathrm{B}$ has a higher protein content $(\%)$ of $16.668 \pm 0.064$. In addition to its nutritional content, the advantage of enteral formula based on local food is its affordable price because it uses the basic ingredients of Tempeh gembus which has a low selling price on the market.

In this study, eight essential amino acids analyzed include isoleucine, leucine, lysine, methionine, phenylalanine, threonine, valine, and histidine, and nine non-essential amino acids include aspartic, glutamate, glycine, proline, serine, tyrosine, alanine, cystine, and arginine supplemented with total amino acids. Table 2 displays the amino acid content and Table 3 displays the average amino acid content in both formulas.

Enteral formulas $\mathrm{A}$ and $\mathrm{B}$ have different weights (a difference of 11 grams from enteral formula A). This happens because the weight obtained is based on the algebraic equation. The nutritional content and caloric value of each ingredient must be known to produce the calculations needed for enteral formulas, namely protein 20 kcal (10\%), fat $60 \mathrm{kcal}(30 \%)$, and carbohydrate $120 \mathrm{kcal}$ $(60 \%)$. This formula is based on recommendations from ASPEN (American Society for Parenteral and Enteral Nutrition) (Brown et al., 2014). Trials were performed to get two appropriate enteral formulas. The suitability of enteral formulas is seen from the presence of sediment between oil and solids.

Overall, the results show that enteral formula A has a total amino acid of $12,610 \mathrm{mg} .100 \mathrm{~g}^{-1} \pm 0.339$ higher than that of enteral formula B of $12,400 \mathrm{mg} .100 \mathrm{~g}^{-1} \pm 0.435$. Meanwhile, the average amino acid content of enteral formula $\mathrm{A}$ of $1,401 \mathrm{mg} .100 \mathrm{~g}^{-1} \pm 2.844$ is also higher than of formula enteral B of $1,378 \mathrm{mg} \cdot 100 \mathrm{~g}^{-1} \pm 2.792$. Enteral formula A contains $2,080 \mathrm{mg} .100 \mathrm{~g}^{-1} \pm 0.0849$ glutamate acid followed by aspartic acid $1,505 \mathrm{mg} .100 \mathrm{~g}^{-1} \pm 0.021$, leucine 1,495 mg. $100 \mathrm{~g}^{-1} \pm 0.035$. Enteral formula B contains 1,950 mg. $100 \mathrm{~g}^{-1} \pm 0.099$ glutamic acids followed by leucine 1,500 mg. $100 \mathrm{~g}^{-1} \pm 0.099$ and aspartic acid $1,360 \mathrm{mg} 100 \mathrm{~g}^{-1} \pm 0.057$. 
Table 2 Amino acid content in enteral formulas A and B in dry weight.

\begin{tabular}{|c|c|c|}
\hline \multirow{2}{*}{ Amino Acid Content } & \multicolumn{2}{|c|}{ Enteral Formula } \\
\hline & $A\left(m g .100 g^{-1} \pm S D\right)$ & B (mg.100g $\left.{ }^{-1} \pm S D\right)$ \\
\hline Aspartic & $1,505 \pm 0.021$ & $1,360 \pm 0.057$ \\
\hline Serine & $650 \pm 0.028$ & $615 \pm 0.021$ \\
\hline Glutamate & $2,080 \pm 0.0849$ & $1,950 \pm 0.099$ \\
\hline Proline & $555 \pm 0.021$ & $545 \pm 0.021$ \\
\hline Glycine & $640 \pm 0.028$ & $625 \pm 0.035$ \\
\hline Alanine & $705 \pm 0.021$ & $675 \pm 0.035$ \\
\hline Cystine & $60 \pm 0.000$ & $65 \pm 0.007$ \\
\hline Tyrosine & $75 \pm 0.007$ & $180 \pm 0.000$ \\
\hline Arginine & $850 \pm 0.071$ & $1,040 \pm 0.14$ \\
\hline Valine & $710 \pm 0.014$ & $685 \pm 0.035$ \\
\hline Methionine & $115 \pm 0.007$ & $120 \pm 0.014$ \\
\hline Dileucine & $625 \pm 0.007$ & $600 \pm 0.028$ \\
\hline Leucine & $1,495 \pm 0.035$ & $1,500 \pm 0.099$ \\
\hline Phenylalanine & $670 \pm 0.028$ & $650 \pm 0.028$ \\
\hline Histidine & $465 \pm 0.021$ & $475 \pm 0.021$ \\
\hline Lysine & $840 \pm 0.057$ & $770 \pm 0.071$ \\
\hline Threonine & $575 \pm 0.007$ & $555 \pm 0.021$ \\
\hline Total Amino Acid & $12,610 \pm 0.339$ & $12,400 \pm 0.435$ \\
\hline
\end{tabular}

Note: Data mean $\pm S D$ with $\mathrm{n}=2$.

Table 3 Average amino acid content in enteral formulas $\mathrm{A}$ and $\mathrm{B}$ in dry weight.

\begin{tabular}{ccc}
\hline Formula Group & Mean $\left(\mathbf{m g . 1 0 0 g ^ { - 1 }}\right)$ & $\boldsymbol{p}^{*}$ \\
\hline A & $1,401 \pm 2.844$ & \multirow{2}{*}{0.812} \\
B & $1,378 \pm 2.792$ & \\
\hline
\end{tabular}

Note: Data mean $\pm S D$ with $\mathrm{n}=2 ; *$ Mann Whitney Test.

Based on all essential amino acids, the highest content in enteral formulas A and B is leucine while the lowest are threonine and histidine. Leucine contributes $27-28 \%$ of the total essential amino acids in both formulas. The amount of six other essential amino acids were found to vary in each enteral formula.

In enteral formulas $\mathrm{A}$ and $\mathrm{B}$, the decrease in the order of essential amino acids after leucine is lysine $>$ valine $>$ phenylalanine $>$ isoleucine $>$ threonine $>$ histidine $>$ methionine. Likewise, the lowest amount of amino acids in enteral formulas A and B is cysteine. This occurred because of the difference in the weight of the composition in the two formulas.

Based on the data normality test using the Shapiro-Wilk test, the data on the average amino acid content of each formula were not normally distributed with $p(0.001)$ $<0.05$; it was then tested using Mann Whitney test with the result that the enteral formulas $\mathrm{A}$ and $\mathrm{B}$ did not have a significant difference with $p(0.812)>0.05$. This is because the difference in the Tempeh gembus flour in each formula is only 11 grams or a very small difference.

Tempeh gembus in this study was hydrolysate with bromelain. Bromelain can break down proteins at the ends of the carbonyl lysine, alanine, tyrosine, and glycine in amino acids. Protein hydrolysate produced with bromelain contains a mixture of bioactive peptides and non-bioactive peptides (Kusumaningtyas et al., 2015), as well as Tempeh gembus added with bromelain or hydrolysate enzymes containing $5.12 \%$ of protein, $67.16 \%$ protein digestibility, and $13.99 \%$ acid amino (Afifah et al., 2019). This is consistent with the results of proximate analysis of protein content in enteral formula $\mathrm{B}$ which has a higher protein content of $1.47 \%$ compared to enteral formula A.

The greater weight of the hydrolysate of Tempeh gembus flour in the enteral formula is the higher the amino acid content will be. However, enteral formula A has a higher average amino acid content compared to enteral formula B. Enteral formula A has $210 \mathrm{mg} .100 \mathrm{~g}^{-1}$ of amino acid higher than formula $\mathrm{B}$.

The main difference in enteral formulas A and B is found in the hydrolysate of Tempeh gembus flour. Other compositions of the two formulas have different weights, but the difference in weight of other compositions is not more than 1 gram. The difference between the enteral formulas $\mathrm{A}$ and $\mathrm{B}$ is related to the higher supporting composition or other composition. Isolated soy protein that has a high protein content has a large influence in increasing amino acid content (Brown et al., 2014); besides, isolated soy protein also has good digestibility (Thrane et al., 2017). Isolated soy protein has to limit amino acids namely methionine, lysine, and less BCAA (Branched Chain Amino Acid) (Luiking et al., 2005). Another composition that contains protein is pumpkin flour. The mixture of the composition of a hydrolysate of Tempeh gembus flour, isolated soy protein, and pumpkin flour can increase the amino acid content in the enteral formula.

The quality of a protein is influenced by digestibility and its amino acid content, which is related to the percentage and proportion of the amino acid itself. Amino acids are fulfilled from the consumption of protein in food, protein breakdown in the body, and synthesis of nonessential amino acids. In infants and toddlers, the role of protein and amino acids occurs during growth through the synthesis of protein in muscles and increased growth. Lysine, methionine, cysteine, threonine, and tryptophan are amino acids that are often deficit in children's food. 
Table 4 Comparison of the conversion of essential amino acids in enteral formulas A and B with amino acid score patterns based on the age of $1-2$ years.

\begin{tabular}{cccccc}
\hline $\begin{array}{c}\text { Amino Acid } \\
\text { Content }\end{array}$ & $\begin{array}{c}\text { Enteral } \\
\text { Formula A } \\
\left(\mathbf{m g . g}^{-1}\right)\end{array}$ & $\begin{array}{c}\text { Enteral } \\
\text { Formula B } \\
\left(\mathbf{m g . g}^{-1}\right)\end{array}$ & $\begin{array}{c}\text { Amino Acid } \\
\text { Pattern (mg) }\end{array}$ & $\begin{array}{c}\text { Amino Acid Score } \\
\text { A }\end{array}$ & Amino Acid Score B \\
\hline Valine & 7.1 & 6.85 & 41 & 17.32 & 16.71 \\
SAA & 1.15 & 1.2 & 25 & 4.6 & 4.8 \\
Ileucine & 6.25 & 6.0 & 31 & 20.16 & 19.35 \\
Leucine & 14.95 & 15.0 & 63 & 23.73 & 23.81 \\
AAA & 6.7 & 6.5 & 46 & 14.57 & 14.13 \\
Histidine & 4.65 & 4.75 & 18 & 25.83 & 26.39 \\
Lysine & 8.4 & 7.7 & 52 & 16.15 & 14.81 \\
Threonine & 5.75 & 5.55 & 27 & 21.29 & 20.56 \\
\hline
\end{tabular}

Note: *FAO Expert Consultation, 2013; * Amino Acid Score were truncated to 1.00, if the score more than 1.00; * SAA (Sulfuric Amino Acid consist of methionine) and AAA (Aromatic Amino Acid consist of phenylalanine).

Children aged $1-2$ years need amino acids containing sulfur (methionine), lysine, threonine, and tryptophan by 25, 52, 27, and $7 \mathrm{mg}$ (FAO Food and Nutrition, 2013). In this study, sulfur amino acid, lysine, and threonine have a higher amino acid than the amino acid pattern in children aged $1-2$.

Lysine supplementation in children can reduce the risk of diarrheal disease that can cause malnutrition and increase body weight significantly. Glutamine amino acids have a significant role in the body to improve the immune system, and glutamine supplementation can improve intestinal mucosal function and increase body weight. The function of glutamate in the digestive system is to facilitate efficient protein digestion because glutamate gives a sweet taste and has physiological and metabolic functions in terms of tissue protection and maintenance (Ghosh and Uauy, 2016). So, the amino acid contained in enteral formulas has good benefits for children with PEM.

Based on Table 4, enteral formulas A and B contain amino acids which can meet daily amino acid in children aged $1-$ 2 years. The amino acid listed by WHO is the lowest level amino acid score from protein intake because overall protein intake is higher. The importance of an optimal amino acid profile and amino acid absorption is related to the response to the digestible protein because the protein requirement comes from nitrogen balance so that protein can be used under any circumstances (FAO Food and Nutrition, 2013). The benefit of consuming protein intake greater than the minimum is increasing muscle mass, muscle strength, and functional results as an increase in health outcomes (Wolfe, 2012). Increased arginine amino acids can synthesize proteins and enhance immune function (Jonker et al., 2012).

The function of assessing the amino acid score is the fulfillment of protein requirements for essential amino acids that are absorbed in the body (Dewi et al., 2010; WHO/FAO/UNU Expert Consultation, 2007). The value of AAS was truncated to 1.00 if the value greater than 1.00 (Hughes et al., 2011). The value amino acid score of methionine (sulfuric amino acid) is a limiting amino acid in enteral formulas A and B. According to Serna-saldivar et al. (2019) and Thrane et al. (2017), methionine and cysteine or sulfuric amino acids are limiting amino acids in soybeans. Likewise, in this study, amino acids containing sulfur were found in low quantities.
Malnutrition problems include stunting, wasting, and PEM; stunted children have essential amino acids (tryptophan, isoleucine, leucine, valine, methionine, threonine, histidine, phenylalanine, and lysine), conditionally essential amino acids (arginine, glycine, and glutamine), and nonessential amino acids (asparagine, glutamate, and serine) are lower than normal children. The decreased amino acids are caused by children not receiving sufficient amino acid food intake (Semba et al., 2016), so the requirements of essential amino acids must be fulfilled because it affects the metabolic processes in the body $(\mathbf{W u}$, 2009).

The total protein and amino acid contents in enteral formulas A and B are different. This is mainly due to the protein testing method used. Protein extraction is also a factor that contributes to the inaccuracy of protein values. Foods that consist of various or heterogeneous nutrients are one cause of the differences in protein values (Wilson and Walker, 2010). The protein content was analyzed using the Kjeldahl method while the amino acid content was analyzed using the High-Performance Liquid Chromatography (HPLC) method. The protein content analysis with the Kjeldahl method based on AOAC 1995 has the principle of determining the nitrogen content of the material as a whole and determining the crude protein. The protein value is obtained from the nitrogen content obtained multiplied by the conversion rate. The calculation error in the Kjeldahl method is because the analyzed nitrogen is sourced from protein, whereas nitrogen also comes from nitrogencontaining compounds such as nucleic acids, alkaloids, chlorophyll, and non-protein additives and contaminants (Utami et al., 2016; Mahre et al., 2018; Jiang et al., 2014). The amount of nitrogen contained in most proteins is $16 \%$ with a conversion factor of 6.25 (Jiang et al., 2014; Mariotti et al., 2008). Overestimation of the 6.25 nitrogen correction factor also causes an increase in protein content (Mæhre et al., 2018; Hall and Schönfeldt, 2013).

The Kjeldahl method also has three analysis stages namely destruction, distillation, and titration (Utami et al., 2016; Mæhre et al., 2018) while the HPLC method consists of four stages of making protein hydrolysate, drying, derivatization, and the injection, and acid amino analysis (Utami et al., 2016). The protein content analyzed by the Kjeldahl method can be smaller than the actual amount due to broken peptide bonds. Besides, amino acids can be 
reduced or even destroyed due to the use of strong acids and the heating process that occurs in the hydrolysis process of the HPLC method (Widya et al., 2019; Hall and Schönfeldt, 2013).

Based on the current study, the enteral formula based on local fermented food can be produced at the household scale. The content of protein and amino acids found in the enteral formula can improve the nutritional status of children because the addition of the bromelain enzyme in Tempeh gembus can break down amino acids into a simpler form.

\section{CONCLUSION}

Enteral formulas A and B that are isocaloric can fulfill the daily needs of amino acids in children aged $1-2$ years. Enteral formula $\mathrm{A}$ has a higher amino acid content of $210 \mathrm{mg} .100 \mathrm{~g}^{-1}$ than enteral formula B, but formula B has a higher protein content of 1.453 grams compared to formula A. The highest amino acid in formulas A and B is glutamate while the limiting amino acid is methionine. Enteral formulas $\mathrm{A}$ and $\mathrm{B}$ based on local food can be an alternative formula for Children with PEM.

\section{REFERENCE}

Afifah, D. N., Rahma, A., Nuryandari, S. S., Alviche, L., Hartono, P. I., Kurniawati, D. M., Wijayanti, S. H., Fitranti, D. Y., Purwanti, R. 2019. Nutrition Content, Protein Quality, and Antioxidant Activity of Various Tempeh gembus Preparations. Journal of Food and Nutrition Research, vol. 7, no. 8, p. 605612. https://doi.org/10.12691/ifnr-7-8-8

Afifah, D. N., Sulchan, M., Syah, D., Yanti,Suhartono, M. 2014. Isolation and Identification of Fobrinolytic ProteaseProducing Microorganism from Red Oncom and Gembus, Indonesian Fermented Soybean Cakes. Malaysian Journal of Microbiology, vol. 10 no. 4, p. 273-279. https://doi.org/10.21161/mjm.61914

Anggraeny, O., Dianovita, C., Putri, E. N., Sastrina, M., Dewi, R. S. 2016. The Correlation of Low Protein Diet Administration on Status of Protein, Immunity, Hemoglobin and Appetite of Male Wistar Rats Rattus norvegicus. Indonesian Journal of Human Nutrition, vol. 3, no. 2, p. $105-$ 22. https://doi.org/10.21776/ub.ijhn.2016.003.02.6

Ariani, D., Angwar, M., Khasanah, Y., Ratnayani, R., Nuraeni, T. 2013. The Feeding of Enteral Nutrition Formulated with Local Food Material Toward the Level of Hemoglobin and Iron in White Rat (Rattus norvegicus). Jurnal Gizi Klinik Indonesia, vol. 10, no. 1, p. 48-54. https://doi.org/10.22146/ijcn.18846

Ashworth, A. 2017.Facility-Based Treatment of Severe Malnutrition. International Encyclopedia of Public Health, Second Edition, vol. 3, p. 77-83. https://doi.org/10.1016/B9780-12-803678-5.00152-1

Astawan, M., Wresdiyati, T., Saragih, A. M. 2015.Evaluation of protein Nutritional Quality of Tempe and Boiled Soybean Flours by Rats. JurnalMutuPangan, vol. 2, no. 1, p.11-7.

Bhutta, Z. A., Salam, R. A. 2012. While Poverty and Socioeconomic Inequity Remains an Important Factor, in Many Cases, the Presence Of Micronutrient Deficiency is a Factor of Diet Quality. Global Nutrition Epidemiology and Trends. Annals Nutrition and Metabolism, vol. 61, p. 19-27. https://doi.org/10.1159/000345167

Boye, J., Wijesinha-bettoni, R., Burlingame, B. 2012.Protein Quality Evaluation Twenty Years after the Introduction of the Protein Digestibility Corrected Amino Acid Score Method. British Journal of Nutrition, vol.108, no. 52, p. 283-211.
https://doi.org/10.1017/S0007114512002309

Brown, B., Roehl, K., Betz, M. 2014. Enteral Nutrition Formula Selection: Current Evidence and Implications for Practice. Nutrition in Clinical Practice, vol. 30, no. 1, p. 72-85. https://doi.org/10.1177/0884533614561791.

Bujang, A., Taib, N. A. 2014. Changes on Amino Acids Content in Soybean, Garbanzo Bean and Groundnut during Pre-treatments and Tempe Making. SainsMalaysiana, vol. 43, no. 4, p. 551-557.

Chusnatayaini, A., Nurikasari, M., Zahroti, A. 2018.Acceptance of Additional Foods Moringa Leaf Modisco Modification. The 2nd Joint international Conferences, p. 99104. ISBN 978-602-5842-03-0.

Cooper, P. A. 2010. The Clinical Challenge of Preventing and Treating Malnutrition. Clinical Nutrition, vol. 66, p. 31-40. https://doi.org/10.1159/000318946

Damayanti, R., Dewi, E., M, M., Soedarjati, S. 2012. Pediatric Nutrition and Metabolic Disease. Volume I. Jakarta: IDAI, p. 51.

Dewi, R. S., Huda, N., Ahmad, R., Abdullah, W. N W. 2010. Protein Quality of Shark Jerky Processed with Different Drying Methods. Jurnal Pascapanendan Bioteknologi Kelautandan Perikanan, vol. 5, no. 1, p. 87-92. https://doi.org/10.15578/jpbkp.v5i1.429

Dietitians Association of Australia. 2018. Enteral Nutrition Manual for Adults in Health Care Facilities. Available at: https://dietitiansaustralia.org.au/wp-

content/uploads/2018/06/Enteral-nutrition-manual-june-2018website.pdf.

FAO Food and Nutrition. 2013. Dietary Protein Quality Evaluation in Human Nutrition. Report of an FAO Expert Consultation.Food and Agriculture Organization of the United Nations. Rome, p. 95. Available at:http:/www.fao.org/ag/humannutrition/35978-

02317b979a686a57aa4593304ffc17f06.pdf

Ghosh, S., Uauy, R. 2016.Protein Quality and Amino Acids in Maternal and Child Nutrition and Health. Encyclopedia of Food and Health, p. 516-523. https://doi.org/10.1016/B978-012-384947-2.00574-2

Gropper, S. S., Smith, J. L. 2013. Advanced Nutrition and Human Metabolism. $6^{\text {th }}$ Ed. Belmont, USA : Yolanda Cossio, p. 390-399. ISBN-13 978-1-133-10405-6.

Hall, N. G., Schönfeldt, H. C. 2013. Total Nitrogen vs Amino-acid Profile as Indicator of Protein Content of Beef. Food Chemistry, vol. 140, no. 3, p. 608-612. https://doi.org/10.1016/j.foodchem.2012.08.046

Hughes, G. J., David, J. R., Ratna, M., Charles, S. S. 2011. Protein Digestibility-Corrected Amino Acid Score (PDCAAS) for Soy Protein IsolatedandConcentrate : Criteria for Evaluation. Journal of Agricultural and Food Chemistry, vol. 59, no. 23, p. 12707-12712. https://doi.org/10.1021/jf203220v

Jiang, B., Tsao, R., Li, Y., Miao, M. 2014. Food Safety: Food Analysis Technologies/Techniques. Encyclopedia of Agriculture and Food Systems, vol. 3, p. 273-288. https://doi.org/10.1016/B978-0-444-52512-3.00052-8

Jonker, R., Engelen, M. P. K. J., Deutz, N. E. P. 2012. Role of Specific Dietary Amino Acids in Clinical Conditions. British Journal of Nutrition, vol. 108, no. 52, p. 139-148. https://doi.org/10.1017/S0007114512002358

Kamalia, A., Sulistyaningsih, E. 2014. The Nutritive Therapy of Modified Modisco with Pineapple Extract Increase Haemoglobin on Severe Protein Energy Malnutrition Rat. $e$ Jurnal Pustaka Kesehatan, vol. 2, no. 1, p. 17-22.

Karyadi, J. N. W., Primawati, Y. F., Bintoro, N. 2012. Drying Process of Grated Cassava (Manihotesculentacrantz) with Pneumatic Drying. In: Proceeding Perteta National Seminar. 
Aceh, p. 96-104.

Knapp, A. W. 2016. Basic Algebra. Digital Second Editions.

Published by the Author, East Setauket, New York, p. 248-295.

Kumaunang, M., Kamu, V. 2010. The Activity Of Bromelain

Enzyme Isolated From Pineapple (Anenascomosus) Fruit Skin.

Jurnal Ilmiah Sains, vol. 11, no. 2, p. 198-201. https://doi.org/10.35799/jis.11.2.2011.207

Kurniasari, R., Sulchan, M., Afifah, D. N., Anjani, G., Rustanti, N. 2017. Influence Variation of Tempe Gembus (an Indonesian Fermented Food) on Homocysteine and Malondialdehyde of Rats Fed an Atherogenic Diet. Romanian Journal of Diabetes Nutrition and Metabolic Disease, vol. 24, no. 3, p. 203-11. https://doi.org/10.1515/rjdnmd-2017-0026

Kusumaningtyas, E., Widiastuti, R., Kusumaningrum, H. D., Suhartono, M. T. 2015. Antibacterial and Antioxidant Activity of Hydolyzate as a Result of Protein Hydrolysis of Goat Milk with Bromelin Rough Extract. JurnalTeknologidanIndustriPangan, vol. 26, no. 2 . https://doi.org/10.6066/jtip.2015.26.2.179

Luiking, Y. C., Deutz, N. E. P., Jakel, M., Soeters, P. B. 2005. Casein and Soy Protein Meals Differentially Affect Whole Body and Splanchnic Protein Metabolism in Healthy Humans. Journal Nutrition, vol. 135, no. 5, p. 1080-1087. https://doi.org/10.1093/jn/135.5.1080

Mariotti, F., Tome, D., Mirand, P. P. 2008.Converting Nitrogen into Protein Beyond 6.25 and Jones' Factors. Critial Reviews in Food Science and Nutrition, vol. 48, no. 2, p. 177184. https://doi.org/10.1080/10408390701279749

Mæhre, H. K., Dalheim, L., Edvinsen, G. K., Elvevoll, E. O., Jensen, I. 2018. Protein Determination-Method Matters. Foods, vol. 7, no. 5, p. $1-11$. https://doi.org/10.3390/foods 7010005

Nakon, P. P. S., Jangchud, K., Jangchud, A., Prinyawiwatkul, W. 2017. Comparisons of Physiochemical Properties and Antioxidant Activities among Pumpkin (Cucurbita moschata L) Flour and Isolated Starches from Fresh Pumpkin or Flour. International Journal of Food Science and Technology, vol. 52, no. 11, p. 1-9. https://doi.org/10.1111/ijfs.13528

Ngo, J., Serra-Majem, L. 2018. Hunger and Malnutrition. Amsterdam, Netherland : Elsevier, p. 1-21.

Pratiwi, L. E., Noer, E. R. 2014. Microbiology Quality Analysis and Viscosity Test of Enteral Formula based on Pumpkin (Curcubita moschata) and Duck Eggs. Journal of Nutrition College, vol. 3, no. 4, p. 951-957. https://doi.org/10.14710/jnc.v3i4.6915

Rauf, R., Utami, A. 2020. Nutrition Value and Viscosity of Polymeric Enteral Nutrition Products based on Purple Sweet Potato Flour with Variation of Maltodextrin Levels. The Indonesian Journal of Nutrition, vol 8, no.2, p. 119-125. https://doi.org/10.14710/jgi.8.2.119-125

Ribarova, F. 2018. Amino Acids: Carriers of Nutritional and Biological Value Foods. In Grumezescu, A. M., Holban, A. M. Food Processing for Increased Quality and Consumption. Amsterdam, Netherland : Elsevier, p. 287-311.

Semba, R. D., Shardell, M., Ashour, F. A. S., Moaddel, R., Trehan, I., Maleta, K. M., Ordiz, M. I., Kraemer, K., Khadeer, M. A., Ferruci, L., Manary, M. J. 2016. Child Stunting is Associated with Low Circulating Essential Amino Acids. Ebio $\begin{array}{llll}\text { Medicine, } & \text { vol. } & 6, & \text { p. }\end{array}$ https://doi.org/10.1016/j.ebiom.2016.02.030

Serna-saldivar, S. O., Perez-carrillo, E., Heredia-olea, E. 2019.Soybean-Fortified Wheat Flour Tortillas. In Preedy, V. R., Watson, R. R. Flour and Breads and their Fortification in Health and Disease Prevention. $2^{\text {nd }}$ ed. Amsterdam, Netherland : Elsevier, p. 291-306. https://doi.org/10.1016/B978-0-12-814639-2.00023-X
Sholihah, Z., Noer, E. R. 2014. Analysis of Nutrient Content and Acceptability of Enteral based for Pumpkin and Duck Eggs. Journal of Nutrition College, vol. 3, no. 4, p.855-861. https://doi.org/10.14710/jnc.v3i4.6891

Sousa, L. R. M., Ferreira, S. M. R., Schieferdecker, M. E. M. 2014. Physiochemical and Nutritional Characteristic of Handmade Enteral Diets. Basil. NutricionHospitalaria, vol. 29, no. 3, p. https://doi.org/10.3305/NH.2014.29.3.7083

Sulchan, M., EndangNur, W. 2007.Nutritional Value and Amino Acid Composition of Tempe Gembus and Its Effect on Growth of Rats. Majalah Kedokteran Indonesia, vol. 57, no. 3, p. $80-85$.

Thrane, M., Paulsen, P. V., Orcutt, M. W., Krieger, T. M. 2017. Soy Protein: Impacts, Production, and Applications. In Nadathur, S. R., Wanasundara, J. P. D., Scanlin, L. Sustainable Protein Sources. Amsterdam, Netherland :Elsevier, p. 23-45. https://doi.org/10.1016/B978-0-12-802778-3.00002-0

UNICEF, WHO., World Bank Group. 2019. Malnutrition Rates Remaining Alarming: Stunting is Declining too Slowly while Wasting Still Impact the Lives of Far too Many Young Children. Available https://data.unicef.org/topic/nutrition/malnutrition/.

UNICEF, WHO., World Bank Group. 2020. Malnutrition Rates Remaining Alarming: Stunting is Declining too Slowly while Wasting Still Impact the Lives of Far too Many Young Children. Available

https://data.unicef.org/topic/nutrition/malnutrition/.

USDA. 2018. United States Department of Agriculture.Agricultural Research Service. USDA Branded Food Products Database. United States. Available at: https://fdc.nal.usda.gov/fdc-

app.html\#/?query=pumpkin\%20flouur.

Utami, P., Lestari, S., Lestari, S. D. 2016.Effects of Cooking Methods on Chemical Composition and Amino Acids Composition of Freshwater Fish (Rasboraargyrotaenia). Jurnal Teknologi Hasil Pertanian, vol. 5, no. 1, p. 73-84.

WHO., FAO., UNU Expert Concultation. 2007. Protein and Amino Acid Requirements in Human Nutrition. Report of a Joint WHO/FAO/UNU Expert Consultation. United Nations University.

Widjaja, N. A., Hidayati, S. N., Irawan, R. 2013. The Influence of Infectious Diseases on Severe Malnutrition in Children's Albumin Levels. Sari Pediatri, vol. 15, no. 1, p. 4650. https://doi.org/10.14238/sp15.1.2013.46-50

Widya, F. C., Anjani, G., Syauqy, A. 2019. Analysis of Protein Levels, Amino Acids and Receiving Food on Supplementary Food (PMT-P) based on Yellow Pumpkin (Cucurbita moschata) for Toddler Malnutrition. Journal of Nutrition College, vol. 8, no. 4, p. 207-218. https://doi.org/10.14710/jnc.v8i4.25834

Wijaya, J. C., Yunianta, Y. 2015. The Effect of Different Bromelain Enzyme Concentration and Incubation Period toward Tempe Gembus's Chemical and Organoleptical Characteristics. Jurnal Pangandan Agroindustri, vol. 3, no. 1, p. 96-106.

Wilson, K., Walker, J. 2010. Principles and Techniques of Practical Biochemistry. Cambridge, UK : Cambridge University Press, p. 300-351.

Wolfe, R. R. 2012. The Role of Dietary Protein in Optimizing Muscle Mass, Function and Health Outcomes in Older Individuals. British Journal of Nutrition, vol. 108, no. 52, p. 88-93. https://doi.org/10.1017/S0007114512002590

WHO. 2009. PelayananKesehatanAnak di RumahSakit [Children's Health Services at the Hospital]. Jakarta: WHO Indonesia. 
https://apps.who.int/iris/bitstream/handle/10665/43206/97897 91947701_ind.pdf?sequence=2\&isAllowed=y.

Wu, G. 2009. Amino Acids: Metabolism, Functions and Nutrition. Amino Acids, vol. 37, p. 1-17. https://doi.org/10.1007/s00726-009-0269-0

\section{Contact address}

Yessie Finandita Pratiwi. Diponegoro University. Faculty of Medicine, Department of Nutrition Science, Semarang, Indonesia, 50275, Phone: +6285735375770 ,

E-mail: yessie.finandita@gmail.com

ORCID: https://orcid.org/0000-0002-4631-238X

Mohammad Sulchan. Diponegoro University. Faculty of Medicine, Department of Nutrition Science, Semarang, Indonesia, 50275, Phone: +62816655235,

E-mail: mohsulchan@gmail.com

ORCID: https://orcid.org/0000-0002-6961-2780
*Diana Nur Afifah. Diponegoro University. Faculty of Medicine, Department of Nutrition Science, Semarang, Indonesia, 50275, Phone: +6287770380468 ,

E-mail: d.nurafifah.dna@fk.undip.ac.id

ORCID: https://orcid.org/0000-0001-8808-1826

Rusdin Rauf. Universitas Muhammadiyah Surakarta. Faculty of Health Science, Surakarta, Indonesia, 57162, Phone: +6281328287438 ,

E-mail: rusdin.rauf@ums.ac.id

ORCID: https://orcid.org/0000-0002-5182-6772

Corresponding author:* 